\title{
Is Internal-External Environment Still Important on MSMEs Competitive Advantage for Business Sustainability During Covid-19 Pandemic?
}

\author{
Adelia Shabrina Prameka ${ }^{1 *}$, Ben Roy Do $^{2}$, Sudarmiatin ${ }^{3}$, Suryo Hadi Wira \\ Prabowo $^{4}$, Rayie Tariaranie Wiraguna ${ }^{5}$ \\ 1,3,4,5 Universitas Negeri Malang, Malang, Indonesia \\ ${ }^{2}$ National Central University, Taoyuan City, Taiwan \\ *Corresponding author. Email: adelia.shabrina.fe@um.ac.id
}

\begin{abstract}
Competitive advantage is a determining factor for a firm's succession and responds to global business competition During COVID-19, MSMEs need to sustain good internal business factors and the government and external stakeholders' role in creating clear policies and guidelines. This study aims to identify and analyse the influence of internal and external environmental factors on Indonesian MSMEs' competitive advantage in the era of the COVID-19 pandemic. The conclusive design used for testing the hypotheses and analyse the relationship among variables. The descriptive quantitative research approach used, which are the phenomena and the problems clearly stated. In this research, Respondents are Indonesia Entrepreneurs ruin business in the seven largest contributors' sectors for Indonesian Gross Domestic Bruto. The findings contribute to a better understanding of competitive advantage for business sustainability during COVID-19 demonstrates the necessity to know and evaluate which factors have influenced the competitive advantage for business sustainability.
\end{abstract}

Keywords: Business sustainability, Competitive advantage, External, Internal.

\section{INTRODUCTION}

The Covid-19 outbreak has proven to bring about daily human life changes, from the economy, politics, culture, and policies to healthy living habits. Changes in the business environment due to this pandemic put excessive pressure and stress on all business activities. Some business actors have also benefited from the pandemic thanks to their speed in adapting to the existing challenges [1]. It shows how important it is for business actors to have the skills to deal with changes that often come suddenly. The Covid-19 pandemic requires everyone, including business people, to avoid direct interactions and transactions.

In one of the KOMPAS newspapers (2020) [2], it is revealed that many business actors are less alert to the changes caused by the pandemic so that the turnover and income of business actors has decreased significantly, even threatened to close. However, not all reports circulating in the mass media show weaker business growth; CNN Indonesia (cnnindonesia.com,
2020) tells the story of business actors who continue to exist amid the pandemic. Thus, business actors' speed to change, anticipate the arrival of change, and adapt to various new trends are suspected factors that significantly affect their business activities' sustainability.

Competitive advantage in every business is now at stake. Micro, Small, and Medium Enterprises (MSMEs) must remain healthy and robust to remain sustainable in the era of the COVID-19 pandemic. Competitive advantage is a determining factor for a firm's succession and responds to global business competition. It is hoped that despite this pandemic, the economic livelihoods of MSMEs will continue with good management of internal business factors and the role of government and external stakeholders to create clear policies and guidelines. Synchronization and implementation of sound management between these two factors can support the movement of business competitiveness. Many factors will contribute to MSME's competitive advantage. 
Here are still limited studies and studies conducted by academic experts who review the Covid-19 pandemic phenomenon in Indonesia's business and entrepreneurial lines. The studies that have been carried out are macroeconomic studies both from the monetary and fiscal side. Few studies discuss what changes occur in internal and external factors in business.

It is fascinating to research so that we, as the general public, know the effects of this pandemic and internalexternal factors that can influence entrepreneurship. Studies related to the relationship of what factors affect entrepreneurship during the COVID-19 pandemic to play a significant role in the Indonesian economy need to be further investigated. This study aims to identify and analyse the influence of the internal and external environment on Indonesian MSMEs' competitive advantage in the era of the COVID-19 pandemic. It is hoped that the internal and external environment will contribute significantly and drive the regional economy.

\section{METHOD}

The conclusive research design used for testing the hypotheses and analyse the relationship among variables. The descriptive studies quantitative research approach is the phenomena and the problems clearly stated. Researchers use a questionnaire for collecting the data. The questionnaires adapt from previous studies and journals by [3], [4] and [5]. The data collected in three months starting from the beginning of the COVID19 coming to Indonesia, when the government enforces the lockdown and Pembatasan Sosial Berskala Besar $(P S B B)$ in Bahasa (April - June 2020). The questionnaires were distributed online through Google Forms. The questionnaires link shared via social media such as Instagram and personal chat apps like WhatsApp as well. Respondents come from 200 Indonesia Entrepreneurs who have business in the seven largest contributors' sectors for Indonesian Gross Domestic Product (GDP). The seven largest contributors' sector in Indonesia GDP, namely, Agriculture, Ranch, Forestry and Fisheries; Trade, Hotel \& Restaurant; Transport \& Communication; Industry Processing; Services; Financial, Leasing and Corporate Services; Construction, Building and Development Services. SPSS version 25 software analysis was used for testing the hypotheses.

\section{RESULTS AND DISCUSSION}

Based on the descriptive analysis of respondent showed that the largest respondent (30.6\%) coming from the Industry Processing sector, and followed by Trade, Hotel \& Restaurant (29.8\%); Services sector (23.7\%); Financial, Leasing and Corporate Services sector (5.3\%); Building and Development Services sector $(3.8 \%)$ same with Transport \& Communication sector $(3.8 \%)$; and the fewest respondents $(3.1 \%)$ were from Agriculture, Ranch, Forestry and Fisheries sector.

For refining and developing a new instrument, factor analysis is outstandingly useful [6]. Following [7] factor analysis can identify with representing the variables from an extensive set of variables, primarily use in subsequent multivariate analyses or creating a new set of variables smaller in partial number or completely replacing the original set of variables, inclusion in subsequent techniques.

The measurement model is an element of the path model that includes indicators and their relationship between constructs. The measurement model includes inter-construct correlation (alpha reliability and Cronbach composite) to evaluate internal consistency and the known or extracted mean-variance with AVE (average variance extracted) to evaluate convergent validity [8].

Table 1 presents reliability; this section consists of 1) Composite Reliability (CR) and 2) Cronbach Alpha. Whereas Table 2 presents the validity, which consists of (1) Average Variance Extracted (AVE) and (2) Correlation Discriminant Validity.

Table 1. Reliability of variables

\begin{tabular}{|l|c|c|}
\hline \multirow{2}{*}{ Construct } & \multicolumn{2}{|c|}{ Reliability } \\
\cline { 2 - 3 } & $\begin{array}{c}\text { Composite } \\
\text { Reliability }\end{array}$ & $\begin{array}{c}\text { Cronbach } \\
\text { Alpha }\end{array}$ \\
\hline $\begin{array}{l}\text { Competitive } \\
\text { Advantage }\end{array}$ & 0.782 & 0.720 \\
\hline External Factor & 0.902 & 0.877 \\
\hline Internal Factor & 0.532 & 0.786 \\
\hline
\end{tabular}

This study's results indicate that of the three existing variables, only one variable, namely External Factor (0.812), is categorized as having satisfactory Cronbach alpha. Meanwhile, Internal Factor's Cronbach alpha (0.782) and Competitive Advantage (0.720) are including in the received reliability category. For composite reliability, it can be seen in the table that the internal factor (0.532) has the lowest value and is including in the low category.

Table 2. Validity

\begin{tabular}{|l|c|c|c|c|}
\hline \multirow{2}{*}{ Construct } & \multirow{2}{*}{ AVE } & \multicolumn{3}{|c|}{ Discriminant Validity } \\
\cline { 3 - 5 } & & CA & EF & IF \\
\hline $\begin{array}{l}\text { Competitive } \\
\text { Advantage }\end{array}$ & 0.561 & 0.749 & & \\
\hline External Factors & 0.509 & 0.611 & 0.713 & \\
\hline Internal Factors & 0.437 & 0.405 & 0.414 & 0.470 \\
\hline
\end{tabular}

Following [7], we can see the measurement of convergent validity through the results of Average Variance Extracted (AVE) and the results of outer loading. AVE is used to measure the amount of variance that can be captured by the construct compared to the 
variance caused by measurement error and must be greater than 0.5 so that $50 \%$ or more of the indicator variance can be accounted for. Internal factors have validity that cannot be accounted for (below 0.50, namely 0.437 ) of the three variables that exist.

The results shown in Table 2 show good discriminant validity because the expected value is that each indicator has a higher loading for the construct being measured compared to the value of cross-loading to other constructs.

Multiple regression analysis was conducted to determine the impact of internal and external factors in creating a competitive advantage and testing the hypothesis. As it could be seen in Table 3.

Table 3. Multiply regression analysis

\begin{tabular}{|l|c|c|}
\hline \multicolumn{1}{|c|}{ Model } & R2 & Adjusted R2 \\
\hline $\begin{array}{l}\text { Competitive } \\
\text { Advantage }\end{array}$ & 0.578 & 0.558 \\
\hline
\end{tabular}

Based on [9] the determinant coefficient (R2) values of $0.75,0.50$, and 0.25 are described as rules for the strong, moderate, and weak criteria. The competitive advantage variable has a moderate $\mathrm{R} 2$ value of 0.578 ; this indicates that the endogenous variable has moderate.

Table 4. Hypothesis testing

\begin{tabular}{|c|c|c|}
\hline \multirow[b]{2}{*}{ Hypothesis } & \multicolumn{2}{|c|}{ Effect } \\
\hline & $\begin{array}{c}\text { Path } \\
\text { Coefficients }\end{array}$ & Support \\
\hline $\begin{array}{ll}\text { H1: } & \text { Internal Factors } \rightarrow \\
& \text { Competitive } \\
& \text { Advantage } \\
\end{array}$ & 0,286 & $\begin{array}{c}\text { Not } \\
\text { Supported }\end{array}$ \\
\hline $\begin{array}{ll}\text { H2: } & \text { External Factors } \rightarrow \\
& \text { Competitive } \\
& \text { Advantage } \\
\end{array}$ & 0,024 & Supported \\
\hline
\end{tabular}

The regression analysis results show that the internal variable factors during this pandemic have a negative relationship. It may be because business actors are still trying to keep their business going, so they do not focus on their business's internal management. The study showed that a positive correlation between external business factors with a competitive advantage. This result is supported by several other previous research.

Our findings contribute to a better understanding of competitive advantage for business sustainability during COVID-19 demonstrates the necessity to know and evaluate which factors have influenced the competitive advantage for business sustainability. External factors play a significant role in the creation of competitive advantages. It is important to remember that external factors have a significant impact on competitive advantage during pandemic COVID-19.

\section{CONCLUSION}

During the COVID-19 pandemic still dangerous, MSMEs need to generate their business's sustainability by initially understanding their internal and external business factors. Find the meaning of four internal aspects: human resource aspects, financial aspects, product, operational aspects, and marketing aspects, primarily before they compete with competitors and have a competitive advantage. It is different from the external factors; entrepreneurs cannot control factors that are coming from external. Uncertainty and competition during six months make entrepreneurs depend on government and stakeholder's regulation and rules. Internal management (internal factor) is one of the leading players in business continuity during a pandemic.

From this research, it can be concluded that Indonesian MSMEs are still not ready to compete again if they have to make changes from internal factors because many aspects still need to be addressed. Many MSMEs provide low score indicators on the questionnaire because they begin to reduce internal management to maintain business continuity in Indonesia. This time of the COVID-19 pandemic.

Indonesian MSMEs must begin to prepare better internal management to bring about renewal and better business feasibility during COVID-19. Optimism from within MSMEs can have a good impact on entering the business competition; many small businesses are more resilient than large-scale businesses. It is shown that the scale of the company or business does not affect the opportunity to maintain a competitive advantage and survive.

\section{REFERENCES}

[1] 2020. J. Turner, and T. Akinremi. "The business effects of pandemics-a rapid literature review. Enterprise Research Centre," [online] available at: https://www.enterpriseresearch.ac.uk/wpcontent/up loads/2020/04/ERC-Insight-The-business-effectsof-pandemics-\% E2. 2020;80.

[2] 2020. Kompas. KOMPAS.

[3] H. Maupa. "Factors determining growth of small and medium enterprises (SMEs) in South Sulawesi:" Dissertation, Hasanuddin University, Unpublished; 2004.

[4] D. Prajogo, and C. M. McDermott. "Antecedents of service innovation in SMEs: Comparing the effects of external and internal factors." Journal of Small Business Management. 2014;52(3):521-40.

[5] Y. B. Kraja, and E. Osmani. "Importance of external and internal environment in creation of 
competitive advantage to SMEs. (Case of SMEs, in the Northern Region of Albania)." European Scientific Journal. 2015;11(13).

[6] J. M. Conway, and A. I Huffcutt. "A review and evaluation of exploratory factor analysis practices in organizational research." Organizational research methods. 2003;6(2):147-68.

[7] J. F. Hair, W. C. Black, B. J. Babin, R. E. Anderson, R. L. Tatham. "Multivariate data analysis:" Prentice hall Upper Saddle River, NJ; 1998.

[8] C. Fornell. "A second generation of multivariate analysis: Classification of methods and implications for marketing research." 1985.

[9] L. Plonsky, H. Ghanbar. "Multiple regression in L2 research: A methodological synthesis and guide to interpreting R2 values." The Modern Language Journal. 2018;102(4):713-31 